\title{
Life is Too Short for Faint-Heartedness: The Archaeology of Andrew Sherratt
}

\author{
Alexander A. Bauer
}

Published online: 25 June 2011

(C) Springer Science+Business Media, LLC 2011

For the British Prehistorian, [a gap in evidence] is a challenge to the imagination, to extrapolate a plausible reconstruction from the nearest kind of evidence available, and by the application of general principles (like Childe's skeuomorphism or Clarke's Mesolithic ecology). The evidence will catch up in its own time: binbir höyük (a thousand and one mounds) await excavation. Life is too short for faintheartedness. (Sherratt 2003a, p. 419)

In writing the above passage, Andrew Sherratt presented perhaps the clearest articulation of who he was as a prehistorian, scholar, and colleague. Never shying away from an intellectual challenge, even if, as he wrote, the evidence had not 'caught up' yet, Andrew did not hesitate to present some hypothesis, and often a synthesis, with the evidence that was at hand-a propensity that was as often a source of frustration (especially to his critics) as inspiration. But Andrew also appreciated a good intellectual fight, and, as suggested in the above passage, always sought to encourage others to debate, explore, challenge current thinking. A common theme among the memorial remarks published by Andrew's colleagues and students is an acknowledgement of his contagious enthusiasm to debate almost any archaeological subject over a coffee or a pint, often leading his interlocutors to consider different perspectives or avenues of inquiry. In an era when the grand syntheses of V. Gordon Childe were non gratae, Andrew's passion for the big picture was both anomalous and liberating, a reassurance that there was still a place for such narratives in archaeology.

Aside from Childe, whose influence on Andrew was immense-his own book of collected essays (Sherratt 1997a) begins and ends with reflections on Childe's contribution to archaeology - the quote above also references David Clarke, Andrew's advisor at Cambridge, whose impact on the field (and Andrew) was almost as significant as Childe's. In one of life's cruel ironies, Andrew's most widely-known contribution to prehistory, the 'Secondary Products Revolution', was introduced in an essay he wrote in memory of

\footnotetext{
A. A. Bauer $(\square)$

Department of Anthropology, Queens College and the Graduate Center, CUNY, 65-30 Kissena Blvd., Flushing, NY 11367, USA

e-mail: alexander.bauer@qc.cuny.edu
} 
Clarke (Sherratt 1981), who had himself died tragically young. The impact of both Childe and Clarke, in some ways opposing forces, is abundantly clear in Andrew's work, both in terms of the questions he was interested in and in his analytical approach to answering them. Like his predecessors, Andrew was primarily concerned with the 'big' issues in European prehistory-from the Mesolithic prelude to agriculture to the advent of ironworking and coinage in the first millennium $\mathrm{BC}$ - but to these problems, he brought a hybrid sensibility that derived in part from each. From Childe, Andrew maintained an interest in technology and the impact that technological innovations could have on society as a whole. Likewise, Andrew believed that such innovations could be either local or borrowed from neighboring societies as a result of larger networks of interaction, exchange, and communication, thus daring to consider diffusion as a serious concept at a time when it was largely rejected by the 'New' archaeological establishment.

Of course, Clarke played a central role in that establishment, with his emphasis on theory building and modeling as laid out in his Analytical Archaeology (Clarke 1968), published while Andrew was studying under him. But this contrast served to add richness to Andrew's thinking, particularly with respect to the role of geography and ecology in influencing and constraining systems of interregional trade and interaction. And from both Childe and Clarke, though in different ways, Andrew maintained a respect for the comparative approach in archaeology: like Clarke, he stressed the significance of ethnographic analogy for generating hypotheses (e.g. Sherratt 1981), and he valued the integration of archaeology with anthropology (which he sought to pass to a new generation of students through the BA program he helped put together at Oxford); like Childe he reveled in comparing and exploring the possible relationships among archaeological cultures, and he dazzled devotees and detractors alike with his almost encyclopedic knowledge of European and Asian cultural history.

Finally, the opening quotation also makes reference to the wide range of questions Andrew was interested in, and the papers in this set, each related to different aspects of Andrew's work, speak to this range as well. While in some ways it is difficult to isolate discrete topics Andrew studied, since it was the interconnectedness of people and ideas that he so relished exploring, it is possible to identify several foci of his work, from specific to general, which the papers here confront in different ways. On the more specific and local end of things, Andrew had a fascination with technological and social practices and their impact on society, and thus researched and wrote a great deal on questions regarding agriculture (Sherratt 1980, 1996a, 1997b, 2004a); animal exploitation (Sherratt 1981, 1987a, 2003b); metallurgy (Sherratt 1976; Sherratt and Taylor 1989; Sherratt and Sherratt 2001); and drinking and feasting rituals (Sherratt 1987b, 1991, 1995c), among others. Although the archaeological record regarding early social practices is in some places thin (and particularly so when Andrew started writing on such issues), his work was impressive in its scope and served to inspire new avenues for inquiry. In his homage to Andrew in this issue, Peter Bogucki presents a similarly synthetic analysis suggesting how economic expansion, new technology, and new forms of social organization (as well as ideological shifts) intersected to facilitate the emergence of 'wealth', physically and symbolically, among European societies of the Late Neolithic. Understanding 'wealth' as a central agent of social differentiation and power, Bogucki's analysis revisits questions about the origins of 'chiefdoms' in Europe and the role that such a conceptual shift may have played in this social transformation, and presents a Sherratt-style hypothesis that seeks to promote further research and discussion.

In Andrew's case, even when that subsequent research was critical, aimed at disproving one of his reconstructions as overly broad, it nevertheless illustrated the significance of his 
contribution in pushing ideas and research forward in new ways. The papers here by Arek Marciniak and David Anthony and Dorcas Brown seek to both refine and challenge Andrew's best known contribution to our understanding of Old World prehistory, the 'Secondary Products Revolution' (SPR). The core idea of the SPR is that the domestication of animals in the Neolithic resulted primarily in the controlled source of meat for consumption, and it was not until much later-during the Early Bronze Age-that the potential of animals to supply 'secondary products' - such as wool and hair for textiles, milk and milk products, and traction power and transport—began to be exploited, resulting in dramatic shifts in economies, land use, and mobility. From its initial presentation (Sherratt 1981), the SPR concept has been subject to criticism, not least for the 'revolution' moniker (itself a bit of a nod to his lasting interest in the social evolutionary models of Childe), but has served to engender a host of subsequent research on the use of such products, and has endured as one of the most powerful concepts introduced in European prehistory over the past 30 years. Part of the reason it has been such a fruitful avenue for inquiry is because recent advances in faunal studies and chemical analyses (such as the study of residues in pottery), and as Marciniak here illustrates, new detailed analyses of faunal remains, unavailable at the time when Andrew first developed the SPR concept, allow us to understand better the complexity of how and when such new human-animal relationships developed. Similarly, Anthony and Brown present a wide range of new data regarding the earliest domestication and use of horses in the Central Asian steppe region, and argue that, contrary to Andrew's original formulation, the riding of horses for transport and warfare, and not simply their use as prestige or pack animals, likely occurred shortly after their domestication in the fourth millennium BC.

How products and cultural practices spread from region to region through trade and interaction was a larger-scale interest for Andrew, leading him to investigate social geographies of consumption, resource procurement, and economic systems, and explore the modeling potentials of World Systems Theory (Wallerstein 1974) and Geographic Information Systems and satellite imagery (as in his ArchAtlas project, at http://www.archatlas.dept.shef.ac.uk). While he found the models of Braudel and Wallerstein intriguing for understanding large-scale and long-term dynamics in European prehistory (Sherratt 1994a, 2000), he shared other archaeologists' skepticism about their potential for archaeology. But rather than simply adopting or casting them aside, Andrew fully engaged with them, in some cases highlighting components that were often neglected in other archaeological discussions, such as the 'margin' in core-periphery schemes (Sherratt 1994b), or the central role of consumption from the periphery in driving both contact and social change (Sherratt 1993a; Sherratt and Sherratt 1991, 2001).

Aside from these broader models, Andrew also examined other mechanisms of connectivity, including language (Sherratt 1999; Sherratt and Sherratt 1988), ideology and ritual (Sherratt 1991, 1995b), and most recently (in a kind of return to his early work in the Hungarian plain and the ecological approach promoted by his mentor, David Clarke), geography and landscape (Sherratt 1996b, 2004b, 2005). In this issue, John O'Shea, who worked with Andrew on his survey in Hungary, considers Andrew's interests in both geography and the Carpathian region to look at how systems of waterways (in this case, rivers) act to connect regions, their people, and resources into larger systems of interaction and exchange. While his case focuses on the Carpathian basin during the Bronze Age, O'Shea's larger point about the dual nature of waterways as both dividing and connecting has resonance for other regions Andrew wrote about, such as the Black Sea (for my own exploration of similar dynamics there, see Bauer 2011), and serves as a prime example of the ways in which large-scale social geographies may be reconsidered. 
Andrew's interest in interconnectedness included archaeological thinking and theorizing itself. While always intrigued by - and often the generator of - 'big ideas', Andrew was not so much a theorist, as Shennan (2006, p. 764) has said, but a 'theoretically informed prehistorian', and despite his sweeping perspective, would always stay well attuned to the archaeological data he was dealing with. In his most overt foray into the debates over archaeological theory that raged in the 1980s and 1990s in particular (Yoffee and Sherratt 1993), he emphasized the interrelationship and complimentarity among different approaches and suggested that archaeologists should work together to develop a set of theories and methods unique to archaeology in order to deal with its particular characteristics and problems. Here, Ian Hodder explicitly takes up Andrew's challenge and presents an integrated approach to the study of the material world and archaeological processes that he terms 'Entanglement Theory'. In seeking to engage with and unify (Hodder's term) small- and large-scale processes and histories, Hodder's contribution may also be seen to confront the shortcomings of the two other large-scale models Andrew was interested in, Braudel's la longue durée and World Systems Theory, which have been criticized (perhaps unfairly so) for not adequately dealing with smaller-scale and shorterterm processes central to archaeology, nor with the interrelationship among interpretive scales. (In fact, Sherratt 2001 himself confronted the issue of the interrelatedness of analytical scales with what he termed a 'structural-interactionist' approach to understanding the past.) To Hodder, 'Entanglement Theory' emphasizes the entanglement of people with the world of things, as well as the relationships which act to constrain and guide social change over short and longer time frames.

Finally, Andrew's broader concerns with modeling larger trends over space and time relate to a third focus of his work, that which examined 'grand narratives' in prehistory such as social evolution and diffusion, and reflected upon their utility for archaeological explanation. Even in this, however, his explorations sought to negotiate large- and smallerscales of analysis, and thus were always grounded in the particular, even mundane, aspects of archaeological data. His efforts to work out the comparative chronologies of the regions he studied-especially elusive for the Eastern European and Circumpontic cultures of the Neolithic and Bronze Age, with which he was perennially concerned-often led him to construct tables of almost unfathomable complexity, documenting each phase and subphase of sites, cultures, and regions. Of course, rapid changes in our knowledge of these early periods (with some rather inconsistent acceptance of calibration for $\mathrm{C} 14$ dates among the scholars of the region) forced Andrew to revise these tables-and thus some of his conclusions-fairly often. As Fred Hiebert observed to me several years ago when we were working on the comparative chronologies of the prehistoric Black Sea region, one need only compare the many chronological charts in his book of collected essays (Sherratt 1997a) to see how the dates of many of the cultures he discussed changed over the course of his career.

In spite of this focus on chronological charts, however, Andrew himself thought that the periodicity and rigidity of such models were often misleading and a distraction from the real issue - the 'Grand Narrative' - that he was interested in (Sherratt 1995a). In her essay here, Barbara Voytek takes up the theme of the Grand Narrative and applies it to a new examination of the European Early Holocene. Voytek provides a new synthesis, regarding the Mesolithic as no longer a 'backwater' between the Epipaleolithic and Neolithic, but rather a dynamic period of transition between the clearly defined environmental and socioeconomic phases that frame it. Apart from building on some of Andrew's views of this period, she additionally invokes the Braudelian concept of la longue durée for her discussion of longer-term environmental rhythms, an idea which Andrew also found compelling (Sherratt 1992). 
In his paper here, Stephen Shennan takes up Andrew's concern with the 'Grand Narrative' by revisiting one of archaeology's grandest, and one that had consumed the attention of his intellectual forbear V. Gordon Childe: 'social evolution'. While social evolutionary thinking may be considered a core concern of archaeology, its acceptance in the discipline has been varied, and criticisms of the scheme-both justified and not-may be seen as a reason that many archaeologists today shy away from writing long-term narratives, as Andrew himself pointed out (1995a). But Shennan proposes that, given the advances made within and outside of anthropology over the past few decades (since the last time the topic was seriously addressed in archaeology), the time is overdue for a reevaluation of social evolutionary thinking and its prospects for archaeological explanation. His essay thus presents both a reassessment of Childe's (1951) contribution to the subject and a new perspective that synthesizes more recent developments, suggesting that social evolution may and should once again be put at the center of archaeological work.

The final paper in this set, by Timothy Taylor, takes us full circle, connecting 'Grand Narrative' back to issues of material and technology, while at the same time addressing Andrew's (1993b) challenge to develop an explicitly archaeological theory. Using an Upper Paleolithic ivory figurine from Brno as a point of departure, Taylor sees the prospects of materiality for engaging a productive relationship between the specific histories of particular artifacts and larger-scale historical narratives. He argues that material objects not only help archaeologists interpret human history but may have themselves been instrumental in how modern humans came to understand the world and their place in it.

Throughout his career, Andrew had an enduring interest in a wide range of subjects: economies and societies, interconnectedness and landscape, and 'Grand Narratives'. In all of these subjects, however, Andrew above all sought to explore and share ideas, and the papers in this issue not only reflect his broad interests but his appreciation for lively debate. It is hoped that these papers in some small measure serve to promote continued exploration of the topics to which Andrew contributed so much. And may we all remember Andrew's example and charge not to be faint of heart. Life is indeed too short for it.

Acknowledgments Most of the papers published in this issue have their origins in a session in memory of Andrew Sherratt presented at the annual meeting of the Society of American Anthropology in Austin, TX, in April 2007. Aside from those who appear here, participants in that session included Peter Biehl, Cyprian Broodbank, Michael Dietler, Richard Evershed and Sebastian Payne, and Norman Yoffee. I would like to thank all those who participated there and here (as well as those who wanted to but could not); the range of papers and enthusiasm for participation is a testament to the affection and respect so many of us felt for Andrew. I would also like to thank Andrew's wife, Susan Sherratt, for her support of this effort and her comments on a draft of this introductory essay. Finally, I would like to thank Tim Taylor for suggesting that these papers be considered as a special issue of the Journal of World Prehistory, a fitting venue for a tribute to Andrew, as his work and influence on prehistory was undeniably global.

\section{References}

Bauer, A. A. (2011). The near East, Europe, and the 'routes' of community in the Early Bronze Age Black Sea. In T. Wilkinson, S. Sherratt, \& J. Bennet (Eds.), Interweaving worlds: Systemic interaction in Eurasia, 7th to 1st millennia BC (pp. 175-188). Oxford: Oxbow.

Childe, V. G. (1951). Social evolution. London: Watts.

Clarke, D. (1968). Analytical archaeology. London: Methuen.

Shennan, S. (2006). Andrew Sherratt remembered. Antiquity, 80, 763-764.

Sherratt, A. (1976). Resources, technology and trade: An essay in early metallurgy. In I. Longworth, G. Sieveking, \& K. Wilson (Eds.), Problems in social and economic archaeology (pp. 557-581). London: Duckworth. 
Sherratt, A. (1980). Water, soil and seasonality in early cereal cultivation. World Archaeology, 11, 313-330.

Sherratt, A. (1981). Plough and pastoralism: Aspects of the secondary products revolution. In N. Hammond, I. Hodder, \& G. Isaac (Eds.), Pattern of the past: Studies in honour of David Clarke (pp. 261-305). Cambridge: Cambridge University Press.

Sherratt, A. (1987a). Wool, wheels and ploughmarks: Local developments or outside introductions in Neolithic Europe? Bulletin of the London University Institute of Archaeology, 23(1986), 1-15.

Sherratt, A. (1987b). Cups that cheered. In W. Waldren \& R. Kennard (Eds.), Bell Beakers of the Western Mediterranean: The Oxford International Conference 1986 (pp. 81-106). Oxford: British Archaeological Reports.

Sherratt, A. (1991). Sacred and profane substances: The ritual use of narcotics in later Neolithic Europe. In P. Garwood, D. Jennings, R. Skeates, \& J. Toms (Eds.), Sacred and profane: Proceedings of a conference on archaeology, ritual and religion, Oxford University Committee for Archaeology Monographs 32, Oxford, pp. 50-64.

Sherratt, A. (1992). What can archaeologists learn from Annalistes? In B. Knapp (Ed.), Archaeology, Annales and ethnohistory (pp. 135-142). Cambridge: Cambridge University Press.

Sherratt, A. (1993a). Who are you calling peripheral? Dependence and independence in European prehistory. In F. Healy \& C. Scarre (Eds.), Trade and exchange in prehistoric Europe (pp. 245-255). Oxford: Oxbow.

Sherratt, A. (1993b). The relativity of theory. In N. Yoffee \& A. Sherratt (Eds.), Archaeological theory: Who sets the agenda? (pp. 119-130). Cambridge: Cambridge University Press.

Sherratt, A. (1994a). What would a Bronze Age world system look like? Relations between temperate Europe and the Mediterranean in later prehistory. Journal of European Archaeology, 1(2), 1-57.

Sherratt, A. (1994b). Core, periphery and margin: Perspectives on the Bronze Age. In C. Mathers \& S. Stoddart (Eds.), Development and decline in the Mediterranean Bronze Age, Sheffield Archaeological Monographs 8, Sheffield, pp. 335-345.

Sherratt, A. (1995a). Reviving the grand narrative: Archaeology and long-term change. Journal of European Archaeology, 3, 1-32.

Sherratt, A. (1995b). Instruments of conversion: The role of megaliths in the Mesolithic-Neolithic transition in north-west Europe. Oxford Journal of Archaeology, 14, 245-260.

Sherratt, A. (1995c). Alcohol and its alternatives: Symbol and substance in early Old World cultures. In A. Sherratt, J. Goodman, \& P. Lovejoy (Eds.), Consuming habits: Drugs in history and anthropology (pp. 11-46). London: Routledge.

Sherratt, A. (1996a). Plate tectonics and imaginary prehistories: Structure and contingency in agricultural origins. In D. Harris (Ed.), Origins and spread of agriculture (pp. 130-140). London: UCL Press.

Sherratt, A. (1996b). Why Wessex? The Avon route in later British prehistory. Oxford Journal of Archaeology, 15, 211-234.

Sherratt, A. (1997a). Economy and society in prehistoric Europe: Changing perspectives. Edinburgh: Edinburgh University Press.

Sherratt, A. (1997b). Climatic cycles and behavioural revolutions: The emergence of modern humans and the beginning of farming. Antiquity, 71, 271-287.

Sherratt, A. (1999). Echoes of the Big Bang: The historical context of language dispersal. In K. Jones-Bley, et al. (Eds.), Proceedings of the Tenth Annual UCLA Indo-European Conference, Los Angeles, CA, May 1998 (Journal of Indo-European Studies Monograph Series No 32) (pp. 261-282). Washington, DC: Institute for the Study of Man.

Sherratt, A. (2000). Envisioning global change: A long-term perspective. In R. Denemark, J. Friedman, \& B. Gills (Eds.), World system history: The social science of long-term change (pp. 115-132). London: Routledge.

Sherratt, A. (2001). World history: An archaeological perspective. In S. Sogner (Ed.), Making sense of global history: The Nineteenth International Congress of the Historical Sciences Oslo 2000 Commemorative Volume (pp. 34-54). Oslo: Universitetsforlaget.

Sherratt, A. (2003a). The Baden (Pécel) culture and Anatolia. In P. Raczky \& E. Jerem (Eds.), Morgenrot der Kulturen: Frühe Etappen der Menschheitsgeschichte in Mittel- und Südosteuropa (pp. 415-429). Budapest: Archaeolingua.

Sherratt, A. (2003b). The horse and the wheel: The dialectics of change in the circum-Pontic and adjacent areas, 4500-1500 BC. In M. Levine, C. Renfrew, \& K. Boyle (Eds.), Prehistoric steppe adaptation and the horse (pp. 233-252). Cambridge: McDonald Institute for Archaeological Research.

Sherratt, A. (2004a). Fractal farmers: Patterns of Neolithic origins and dispersal. In J. Cherry, C. Scarre, \& S. Shennan (Eds.), Explaining social change: Studies in honour of Colin Renfrew (pp. 53-63). Cambridge: McDonald Institute for Archaeological Research. 
Sherratt, A. (2004b). Spotting tells from space. Antiquity: (Project Gallery) 78(301), September 2004, at http://antiquity.ac.uk/ProjGall/sherratt/.

Sherratt, A. (2005). TransTaurus: Early connections between central and southeast Anatolia. Anatolian Archaeology, 11, 24-26.

Sherratt, A., \& Sherratt, S. (1988). The archaeology of Indo-European: An alternative view. Antiquity, 62, 584-595.

Sherratt, A., \& Sherratt, S. (1991). From luxuries to commodities: The nature of Mediterranean Bronze Age trading systems. In N. Gale (Ed.), Bronze Age trade in the Mediterranean. Studies in Mediterranean Archaeology 90 (pp. 351-386). Jonsered: Paul Åströms Förlag.

Sherratt, A., \& Sherratt, S. (2001). Technological change in the East Mediterranean Bronze Age: Capital, resources and marketing. In A. Shortland (Ed.), The social context of technological change (pp. 15-38). Oxbow: Oxford.

Sherratt, A., \& Taylor, T. (1989). Metal vessels in Bronze Age Europe and the context of Vulchetrun. In J. Best \& N. de Vries (Eds.), Thracians and Mycenaeans (pp. 106-134). Brill: Leiden.

Wallerstein, I. (1974). The modern world-system, vol. I: Capitalist agriculture and the origins of the European world-economy in the sixteenth century. New York: Academic Press.

Yoffee, N., \& Sherratt, A. (Eds.). (1993). Archaeological theory: Who sets the agenda? Cambridge: Cambridge University Press. 